\title{
Relationship between Acute Phase Reactants, Visceral Proteins, and Biochemical Indicators of Iron Status in a Free Living Population of Children
}

\author{
Pilar Galan,* Miguel Davila, Daniel Sess, \\ Nadia MeKki, and Serge Hercberg \\ The Centre de Recherche sur les Anémies Nutritionnelles, \\ Institut Scientifique et Technique de l'Alimentation, CNAM, \\ 2, rue Conté, F-75003, Paris, France
}

(Received July 6, 1987)

\begin{abstract}
Summary Indicators of iron status and protein status as well as markers of inflammatory processes were determined in 164 apparently healthy children 4 years old ( \pm 3 months) undergoing a free medical check-up in a Parisian Children's Health Examination Center. Biochemical evidence of inflammatory syndrome (without clinical signs) was observed in 32 children. Among the indicators of protein status, only the mean thyroxine-binding prealbumin was significantly lower in the group of children with inflammation than in the inflammation-free group. Among indicators of iron status, mean serum iron and transferrin saturation were significantly lower, and mean serum ferritin, significantly higher, in children with inflammatory processes. Seventy-eight percent of children with biochemical inflammatory processes had serum ferritin levels higher than $50 \mu \mathrm{g} /$ liter, and $42 \%$ had serum ferritin levels higher than $80 \mu \mathrm{g} /$ liter.

Our study shows that mild inflammatory processes are not uncommon in young, apparently healthy children and may affect the capacity of prealbumin to reflect protein status as well as the capacity of most iron parameters to assess iron status. Serum ferritin, serum iron, and transferrin saturation seem to be most affected by the presence of a mild inflammatory reaction.
\end{abstract}

Key Words: iron status, visceral proteins, inflammation, acute phase reactants, serum ferritin

Inflammation is known to cause a complex response in man. Focal reactions are associated with systemic reactions which are characterized by a considerable

*To whom correspondence should be addressed. 
increase in the serum concentration of certain proteins. In particular, the synthesis of several serum proteins, the "acute phase reactants," increases in the case of inflammation. Among these, $\alpha_{1}$ acid glycoprotein (orosomucoid) and C-reactive protein (CRP) have been identified as the most sensitive parameters in inflammatory syndromes [1]. Inflammatory processes are also known to interfere with various biochemical indicators of nutritional status and particularly of protein and iron status $[2,3]$. However, most previous surveys which studied such interference were performed in developing countries or on patients presenting severe pathology such as inflammatory joint disease [4], inflammatory bowel disease [5], ulcerative colitis [6], or severe malnutrition [1]. Few studies have investigated the consequences of mild inflammatory processes, frequently observed in young children, on the biochemical measurements of nutritional status in industrialized countries.

The purpose of the present study was to examine the consequences of inflammatory processes without clinical signs but identified by biochemical markers with respect to biochemical indicators of protein and iron status in a free-living population of children in an industrialized country.

\section{SUBJECTS AND METHODS}

The sample was selected from children 4 years old ( \pm 3 months) undergoing a free medical check-up at a Parisian Children Health Examination Center. One hundred-sixty-four children (mean age $\pm \mathrm{SD}=48.3 \pm 0.9$ months) were invited to participate in the survey. Mean weight $( \pm$ SD) and mean size $( \pm$ SD) were, respectively, $16.5 \pm 2.1 \mathrm{~kg}$ and $102.2 \pm 4.1 \mathrm{~cm}$. All children were apparently healthy and well nourished. None was taking drugs or mineral or vitamin supplements at the time of the survey.

A fasting venous blood sample $(1 \mathrm{ml})$ was collected at 8 a.m. for the following assays: hemoglobin and red cell indices (Coulter Model 5, Coultronic France, Margency), erythrocyte protoporphyrin (Automatic Model 5 Hematofluorometer, Aviv Biomedical, Analis, Namur), serum iron (colorimetric method using Ferrozine [7] adapted to an ABA 100 analyzer, Abbott, Rungis), and serum ferritin (enzyme-linked immunosorbent assay [8] standardized using the international reference, NIBSC, London). CRP, orosomucoid, serum albumin, serum transferrin, thyroxine-binding prealbumin (TBPA), and retinol-binding protein (RBP) were measured by nephelometry [9] using a laser nephelometer (Behring, RueilMalmaison).

Total iron-binding capacity (TIBC) was deduced from transferrin concentration. Percent transferrin saturation was calculated by multiplying the ratio of serum iron to TIBC by 100 .

Statistical analysis was carried out using Student's $t$-test, the $\mathrm{Chi}^{2}$ test, and Pearson's correlation coefficient, $r$. Since serum ferritin approached a log normal distribution, a log transformation was used for all calculations. 


\section{RESULTS}

An inflammatory syndrome was considered to be present when the CRP concentration was above $12 \mathrm{mg} /$ liter and/or the orosomucoid level was above $1.4 \mathrm{~g} /$ liter. According to this definition, 32 children presented biochemical evidence (without clinical signs) of an inflammatory process (Group I) and 132 were free of it (Group II). Age and anthropometric data were not different in the two groups. The mean $( \pm \mathrm{SD})$ and percentage of abnormal values for laboratory measurements of nutritional status of the two groups are listed in Table 1. Measurements of

Table 1. Nutritional indicators of children with (Group I) or without (Group II) subclinical inflammation.

\begin{tabular}{|c|c|c|}
\hline & $\underset{(n=32)}{\text { Group I }}$ & $\begin{array}{l}\text { Group II } \\
(n=132)\end{array}$ \\
\hline \multicolumn{3}{|l|}{ Hemoglobin $(\mathrm{g} / \mathrm{dl})$} \\
\hline mean $\pm \mathrm{SD}$ & $12.3 \pm 0.8$ & $12.3 \pm 0.9$ \\
\hline abnormal values $(\%)$ & 0 & 3.8 \\
\hline \multicolumn{3}{|l|}{$\operatorname{MCV}(f l)$} \\
\hline mean $\pm \mathrm{SD}$ & $79.9 \pm 3.2$ & $80.2 \pm 4.5$ \\
\hline abnormal values $(\%)$ & 0 & 5.3 \\
\hline \multicolumn{3}{|l|}{ Serum iron $(\mu \mathrm{mol} /$ liter $)$} \\
\hline mean $\pm \mathrm{SD}$ & $9.0 \pm 4.3$ & $12.9 \pm 5.5^{*}$ \\
\hline abnormal values $(\%)$ & 46.9 & 28.7 \\
\hline \multicolumn{3}{|l|}{ Transferrin saturation $(\%)$} \\
\hline mean $\pm \mathrm{SD}$ & $11.3 \pm 5.0$ & $16.3 \pm 7.1^{+}$ \\
\hline abnormal values $(\%)$ & 86.7 & 51.2 \\
\hline \multicolumn{3}{|c|}{ Erythrocyte protoporphyrin $(\mu \mathrm{g} / \mathrm{g} \mathrm{Hb})$} \\
\hline mean $\pm \mathrm{SD}$ & $2.5 \pm 0.6$ & $2.4 \pm 0.7$ \\
\hline abnormal values $(\%)$ & 12.5 & 11.4 \\
\hline \multicolumn{3}{|l|}{ Serum ferritin $(\mu \mathrm{g} /$ liter $)$} \\
\hline mean $\pm \mathrm{SD}$ & $86.5 \pm 56.1$ & $46.1 \pm 32.0$ \\
\hline geometric mean & 73 & $38 * *$ \\
\hline abnormal values $(\%)$ & 0 & 17.4 \\
\hline \multicolumn{3}{|l|}{ Serum albumin (g/liter) } \\
\hline mean $\pm \mathrm{SD}$ & $45.1 \pm 5.6$ & $46.8 \pm 6.4$ \\
\hline abnormal values $(\%)$ & 0 & 0 \\
\hline \multicolumn{3}{|l|}{ Serum transferrin ( $\mathrm{g} /$ liter) } \\
\hline mean $\pm \mathrm{SD}$ & $3.1 \pm 0.5$ & $3.3 \pm 0.3$ \\
\hline abnormal values $(\%)$ & 0 & 0 \\
\hline \multicolumn{3}{|l|}{ TBPA (mg/liter) } \\
\hline mean $\pm \mathrm{SD}$ & $180 \pm 50$ & $220 \pm 50^{*}$ \\
\hline abnormal values $(\%)$ & 12.5 & 0 \\
\hline \multicolumn{3}{|l|}{ RBP } \\
\hline mean $\pm \mathrm{SD}$ & $41.2 \pm 17.1$ & $43.7 \pm 13.4$ \\
\hline abnormal values $(\%)$ & 18.7 & 8.3 \\
\hline
\end{tabular}

Vol. 3, No. 3, 1987 
nutritional status were considered to be abnormal at the following levels: hemoglobin less than $11 \mathrm{~g} / \mathrm{dl}$, mean corpuscular volume (MCV), less than $73 \mathrm{fl}$, serum iron (SI), less than $10 \mu \mathrm{mol} / \mathrm{liter}$, TIBC, higher than $95 \mu \mathrm{mol} / \mathrm{liter}$; transferrin saturation (TS), less than $16 \%$; erythrocyte protoporphyrin (EP), less than 3 $\mu \mathrm{g} / \mathrm{g}$ of hemoglobin; serum ferritin (SF), $12 \mu \mathrm{g} /$ liter or less; serum albumin, less than $35 \mathrm{~g} /$ liter; TBPA, less than $100 \mathrm{mg} /$ liter; RBP, less than $30 \mathrm{mg} / \mathrm{liter}$; and serum transferrin, less than $2 \mathrm{~g} /$ liter.

Mean SI, TS, and TBPA values were significantly lower and SF concentrations, significantly higher, in Group I. No children had abnormal values for serum albumin and serum transferrin. Four children had a TBPA level of $100 \mathrm{mg} /$ liter or less: 3 of them had an inflammatory process. Out of 17 children with an RBP concentration of less than $30 \mathrm{mg} /$ liter, 6 had an inflammatory syndrome.

In Group I, no children had SF values in the range corresponding to depleted iron stores (less than $12 \mu \mathrm{g} /$ liter), but in Group II, 23 children $\left(17.4^{\circ} \%\right.$ ) were in this category. Conversely, the percentage of children with a low SI concentration and low TS coefficient was significantly higher in Group I. Seventy-eight percent of children with an inflammatory process had SF levels higher than $50 \mu \mathrm{g} /$ liter and $42 \%$ had one higher than $80 \mu \mathrm{g} /$ liter.

Numbers and percentages of children (with or without inflammatory process) presenting a combination of abnormalities for the main indicators of iron status are presented in Table 2. Depleted iron stores, defined by an isolated low SF concentration ( $\mathrm{SF} \leq 12 \mu \mathrm{g} /$ liter), were observed in 3 cases. Clear-cut iron deficiency, defined by a low SF concentration associated with a high EP level $(>3 \mu \mathrm{g} / \mathrm{g}$ of hemoglobin) and/or a low TS $(<16 \%$ ) was present in 20 children; all were free of inflammation. In 4 children, iron deficiency was associated with anemia. The association of a low TS percentage and a high EP level with an SF concentration higher than $12 \mu \mathrm{g} /$ liter was observed in 14 cases. In this group, of the 9 children with an SF level less than $80 \mu \mathrm{g} /$ liter, only one had biochemical evidence of inflammatory syndrome. Conversely, of the 5 children with $\mathrm{SF}>80 \mu \mathrm{g} / \mathrm{liter}, 4 \mathrm{had}$ this syndrome.

Correlation analysis showed that CRP and orosomucoid were positively correlated with one another $(r=0.38, p<0.01)$. TBPA was positively correlated

Table 2. Number of children presenting different combinations of abnormal indicators of iron status.

\begin{tabular}{lcc}
\hline & $\begin{array}{c}\text { Total number } \\
\text { of cases }\end{array}$ & $\begin{array}{c}\text { Number of cases } \\
\text { with inflammatory } \\
\text { processes* }\end{array}$ \\
\hline $\mathrm{SF} \leqslant 12 \mu \mathrm{g} /$ liter, $\mathrm{TS}>16 \%$, and $\mathrm{EP}<3 \mu \mathrm{g} / \mathrm{g} \mathrm{Hb}$ & 3 & 0 \\
$\mathrm{SF} \leqslant 12 \mu \mathrm{g} /$ liter, $\mathrm{TS}<16 \%$, and $/ \mathrm{or} \mathrm{EP}>3 \mu \mathrm{g} / \mathrm{g} \mathrm{Hb}$ & 20 & 0 \\
$13 \mu \mathrm{g} / \mathrm{liter}<\mathrm{SF} \leqslant 80 \mu \mathrm{g} / \mathrm{liter}, \mathrm{TS}<16 \%$, and EP $>3 \mu \mathrm{g} / \mathrm{g} \mathrm{Hb}$ & 9 & 1 \\
$\mathrm{SF}>80 \mu \mathrm{g} /$ liter, $\mathrm{TS}<16 \%$, and $\mathrm{EP}>3 \mu \mathrm{g} / \mathrm{g} \mathrm{Hb}$ & 5 & 4 \\
\hline
\end{tabular}

\footnotetext{
* $\mathrm{CRP}>12 \mathrm{mg} / \mathrm{liter}$ and/or orosomucoid $>1.4 \mathrm{~g} / \mathrm{liter}$
} 
Table 3. Correlations between inflammatory markers and indicators of iron status.

\begin{tabular}{lcccccccc}
\hline & CRP & Hemoglobin & MCV & $\begin{array}{c}\text { Serum } \\
\text { iron }\end{array}$ & $\begin{array}{c}\text { Transferrin } \\
\text { saturation }\end{array}$ & $\begin{array}{c}\text { Erythrocyte } \\
\text { protoporphyrin }\end{array}$ & $\begin{array}{c}\text { Serum } \\
\text { ferritin }\end{array}$ \\
\hline Orosomucoid & $0.38^{*}$ & 0.00 & 0.00 & $-0.33^{*}$ & $-0.21^{+}$ & 0.00 & $0.33^{*}$ \\
CRP & - & 0.00 & 0.00 & $-0.26^{\prime}$ & $-0.28^{*}$ & 0.00 & $0.33^{*}$ \\
Hemoglobin & & - & $0.47^{*}$ & 0.20 & $0.21^{+}$ & $-0.36^{*}$ & 0.12 \\
MCV & & & - & $0.27^{*}$ & $0.28^{*}$ & $-0.43^{*}$ & $0.27^{*}$ \\
Serum iron & & & & - & $0.87^{*}$ & $-0.25^{\prime}$ & 0.12 \\
Transferrin saturation & & & & - & $-0.21^{+}$ & 0.13 \\
Erythrocyte protoporphyrin & & & & & - & - & 0.11 \\
\hline & ${ }^{+} p<0.05 ;^{\prime} p<0.02 ;{ }^{*} p<0.01$ & & & & & &
\end{tabular}

with serum albumin $(r=0.28, p<0.01)$, RPB $(r=0.40, p<0.01)$, and serum transferrin $(r=0.21, p<0.05)$ and negatively correlated with orosomucoid $(r=-0.25$, $p<0.02)$ and CRP $(r=-0.22, p<0.05)$. RBP and serum albumin were positively correlated $(r=0.21, p<0.05)$. Correlation coefficients for the various parameters of iron status and inflammatory markers are listed in Table 3. Indicators of iron status were significantly correlated with one another. SF, SI, and TS were correlated with inflammatory markers.

\section{DISCUSSION}

The evaluation of nutritional status requires the use of reliable indicators. The most useful tests are those which have the highest sensitivity, highest specificity, and lowest variability. In the assessment of protein depletion, serum albumin is considered to respond with low sensitivity; serum transferrin, with intermediate; and serum TBPA-RBP complex, with the highest sensitivity [10]. Serum TBPA, with its very high turnover rate (half-life: 1.9 days), has been recognized as the first blood protein to significantly decrease as a result of borderline protein intake in apparently healthy children [11]. However, low serum TBPA levels have been reported in some pathological conditions and surgical traumas, independent of the nutritional status $[12,13]$. These situations are not usually observed in freeliving populations and do not constitute a major inconvenience in field assessment of the nutritional status of communities. Conversely, our study shows that mild inflammatory processes (without clinical evidence) are common in young, apparently healthy children and may affect the capacity of TBPA to reflect protein status. This may represent a major difficulty in interpreting the significance of this parameter, when used as a screening tool for nutritional status, if tests for inflammatory markers are not performed at the same time.

The same problem exists in the evaluation of iron status of individuals and populations. To assess iron status, serum ferritin has been demonstrated as being most sensitive, as it is directly proportional to the body level of iron stores [14, 15]. Serum iron, TIBC, and erythrocyte protoporphyrin measurements are less

Vol. 3, No. 3, 1987 
sensitive, though they provide information on the adequacy of the iron supply to the erythroid marrow $[3,15]$. However, each of these indicators may also be affected by the co-existence of confounding factors, particularly infection and inflammatory syndromes. This has been well demonstrated in a tropical context, in which these situations are very common, or in seriously ill patients with chronic infections [16-18]. Severe inflammatory syndromes are considered to be responsible for a decrease in the percentage of transferrin saturation, an increase in the erythrocyte protoporphyrin concentration, and a very high rise in the serum ferritin level $[3,15,19]$. The decrease in the percent of transferrin saturation is explained by a decreasing serum iron level linked to immobilization of iron in the reticulo-endothelial system during inflammation [20]. It has been suggested that the rise in the serum ferritin level is caused by an augmentation of ferritin synthesis rather than by a release of ferritin from inflammatory cells [21]. Thus, the use of transferrin saturation and/or erythrocyte protoporphyrin concentration as indicators of iron status may cause an incorrect diagnosis of iron deficiency in populations presenting inflammatory syndromes. Conversely, the use of serum ferritin could lead to a diagnosis of iron sufficiency in true iron-depleted subjects and an underestimation of the prevalence of iron deficiency. The usual approach, of separating normal from iron-deficient subjects on the basis of only one criterion, inevitably involves errors in the diagnosis of both normal and iron-deficient subjects.

Our work suggests that even in apparently healthy children living in industrialized countries, the relative importance of mild inflammation should be taken into account to assess iron status. The choice of a combination of several indicators influenced differently by inflammatory processes is essential to increase the specificity of the diagnosis of iron deficiency. In our study, serum ferritin, serum iron, and transferrin saturation seem to be the parameters most affected by the existence of an inflammatory reaction.

This work was supported by Institut National de la Santé et de la Recherche Médicale Grant $N^{\circ} 848009$.

We thank Mrs Rossignol, Mrs Farnier and all the technical staff of the Centre Parisien de Bilan de Santé de l'Enfant (CPAM, Paris) for their helpful assistance.

\section{REFERENCES}

1. Ingenbleek, Y., and Carpentier, Y.A. (1985): A prognosic inflammatory and nutritional index scoring critically ill patients. Int. J. Vitam. Nutr. Res., 55, 91-101.

2. Belfrage, S. (1963): Plasma protein patterns in the course of acute infectious disease. Acta Med. Scand., 173, Suppl., 395, 1-169.

3. Hercberg, S., and Galān, P. (1985): Assessment of iron deficiency in populations. Rev. Epidemiol. Santé Publique, 33, 228-239.

4. Bentley, D.P., and Williams, P. (1974): Serum ferritin concentrations as an index of storage iron in rheumatoid arthritis. J. Clin. Pathol., 27, 786-788.

5. Bartels, U., Pedersen, N.S., and Jarnum, S. (1978): Iron absorption and serum ferritin in 
chronic inflammatory bowel disease. Scand. J. Gastroenterol., 13, 649-656.

6. Buckell, N.A., Lennard-Jones, J.E., Hernandez, M.A., Kohn, J., Riches, P.G., and Wadsworth (1979): Measurement of serum proteins during attacks of ulcerative colitis as a guide to patient management. Gut, 20, 22-27.

7. Giovanello, T.J., Di Benedetto, G., Palmer, D.W., and Peters, T., Jr. (1968): Fully and semi-automated methods for the determination of serum iron and total-iron-binding capacity. J. Lab. Clin. Med., 71, 874-880.

8. Voller, A., and De Savigny, D. (1981): Enzyme-linked immunosorbent assay (ELISA), in Techniques in Clinical Immunology (2nd Ed.), ed. by Thomson, R.A., Blackwell Scientific Publication, pp. 157-168.

9. Conrad, A., Schurmann, J., Kreutz, F.H., and Sieber, A. (1978): Elaboration of a method for the quantitative determination of proteins by laser nephelometry in the clinical routine laboratory. J. Clin. Chem. Clin. Biochem., 16, 299-305.

10. Ingenbleek, Y., Van der Schrieck, H.G., De Nayer, P., and De Visscher, M. (1975): Albumin, transferrin and the thyroxine-binding prealbumin/retinol-binding protein (TBPARBP) complex in assessment of malnutrition. Clin. Chim. Acta, 63, 61-67.

11. Inglenbleek, Y., De Visscher, M., and De Nayer, P. (1972): Measurement of prealbumin as an index of protein-calorie malnutrition. Lancet, ii, 106.

12. Bellabarba, D., Inada, M., Varsano-Aharon, N., and Sterlin, K. (1968): Thyroxine transport and turn over in major non-thyroidal illness. J. Clin. Endocrinol., 28, 1023-1025.

13. Agostini, A., Vergani, C., Stabilini, R., and Petrella, A. (1968): Thyroxine binding prealbumin in alcoholic cirrhosis. Lancet, i, 926.

14. Walters, G.O., Miller, F., and Worwood, M. (1973): Serum ferritin concentration and iron stores in normal subjects. J. Clin. Pathol., 26, 770-772.

15. Cook, J.D. (1982): Clinical evaluation of iron deficiency. Semin. Hematol., 19, 8-18.

16. Hercberg, S., Galān, P., Chauliac, M., Masse-Raimbault, A.M., Devanlay, M., Alihonou, E., Bileoma, S., Zohoun, I., Christides, J.P., and Potier de Courcy, G. (1987): Nutritional anaemia in Beninese pregnant women: consequence on haematological profile of newborn. Br. J. Nutr., 57, 185-193.

17. Hercberg, S., Galān, P., Chauliac, M., Zohoun, I., and Masse-Raimbault, A.M. (1987): Iron status and inflammatory processes in anemic children. J. Trop. Pediatr., 33, 168-172.

18. Birgegard, G., Hallgren, R., Killander, A., Stromberg, A., Venge, P., and Wide, L. (1978): Serum ferritin during infection-a longitudinal study. Scand. J. Haematol., 21, 333-340.

19. Blake, D.R., Waterworth, R.F., and Bacon, P.A. (1981): Assessment of iron stores in inflammation by assay of serum ferritin concentrations. Br. Med. J., 283, 1147-1148.

20. Cartwright, G.E., and Lee, G.R. (1971): The anemia of chronic disorders. Br. J. Haematol., 21, 147-152.

21. Kojnin, A.M., and Hershko, C. (1977): Ferritin synthesis in inflammation. Pathogenesis of impaired iron release. Br. J. Haematol., 13, 924-933. 